Canadian

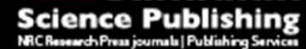

Canadian Journal of Microbiology Revue canadienne de de microbiologie

\title{
Identification of Shigella flexneri isolates carrying Shiga Toxin 1-producing gene in Quebec, Canada linked to travel to Haiti.
}

\begin{tabular}{|r|l|}
\hline Journal: & Canadian Journal of Microbiology \\
\hline Manuscript ID & cjm-2015-0538.R1 \\
\hline Manuscript Type: & Letter \\
\hline Date Submitted by the Author: & $01-$ Sep-2015 \\
\hline Complete List of Authors: & $\begin{array}{l}\text { Bekal, Sadjia; Laboratoire de Santé Publique du Québec/Institut National } \\
\text { de Santé Publique du Québec; Université de Montréal, Département de } \\
\text { Microbiologie, Infectiologie et Immunologie } \\
\text { Pilon, Pierre A.; Agence de la santé et des services sociaux de Montréal; } \\
\text { Université de Montréal, ; } \\
\text { Cloutier, Nancy; Laboratoire de Santé Publique du Québec/Institut National } \\
\text { de Santé Publique du Québec } \\
\text { Doualla-Bell, Florence; Laboratoire de Santé Publique du Québec/Institut } \\
\text { National de Santé Publique du Québec; McGill University, Department of } \\
\text { Medicine, Division of Experimental Medicine } \\
\text { Longtin, Jean; Laboratoire de Santé Publique du Québec/Institut National } \\
\text { de Santé Publique du Québec; Centre de recherche en infectiologie de } \\
\text { I'Université Laval }\end{array}$ \\
\hline Keyword: & \begin{tabular}{l} 
<i>Shigella flexneri </i>, shiga toxin 1 gene \\
\hline
\end{tabular} \\
\hline
\end{tabular}

\section{SCHOLARONE \\ Manuscripts}


Identification of Shigella flexneri isolates carrying Shiga Toxin 1-producing gene in Quebec,

2 Canada linked to travel to Haiti.

4 Sadjia Bekal Laboratoire de Santé Publique du Québec/Institut National de Santé Publique du

5 Québec, Sainte-Anne-de-Bellevue, Québec, Canada/Département de Microbiologie, Infectiologie

6 et Immunologie, Université de Montréal, Montréal, Québec, Canada

7 Pierre A. Pilon Direction régionale de santé publique de Montréal, Québec, Canada

$8 \quad$ Nancy Cloutier Laboratoire de Santé Publique du Québec/Institut National de Santé Publique du

9 Québec, Sainte-Anne-de-Bellevue, Québec, Canada

Florence Doualla-Bell Laboratoire de Santé Publique du Québec/Institut National de Santé

Publique du Québec, Sainte-Anne-de-Bellevue, Québec, Canada/ Department of Medicine,

12 Division of Experimental Medicine, McGill University, Montréal, Québec, Canada

Jean Longtin Laboratoire de Santé Publique du Québec/Institut National de Santé Publique du Québec, Sainte-Anne-de-Bellevue, Québec, Canada/ Centre de recherche en infectiologie de 1’Université Laval, Québec, Canada

Address correspondance to Sadjia Bekal : $\underline{\text { sadjia.bekal@inspq.qc.ca }}$

Running title: Shigella flexneri carrying Stx1 in Quebec, Canada 


\section{Letter to the Editor}

Shiga toxins (Stx1 and Stx2, also called verocytotoxins) are commonly associated with Shiga toxin-producing E. coli (STEC) and Shigella dysenteriae type 1 (Tesh and O'Brien 1991). Recent studies have documented cases of stx carriage in other Shigella species, including S. sonnei linked to travel to Morocco (Nyholm et al. 2015) and S. flexneri with travel history to Caribbean (Gray et al. 2015; Gray et al. 2014). More than forty percent of Shigellosis cases are travelrelated in the province of Quebec (Trepanier et al. 2014). Therefore, a retrospective laboratory study was performed by the laboratoire de santé publique du Québec to assess the presence of stx gene among the 210 strains of Shigella isolated between 2013 and 2014. The collection included 131 S. sonnei, 75 S. flexneri, 3 S. boydii and 1 S. dysenteriae type 12. PCR targeting stx1 and stx2 was performed according to Paton and Paton (Paton and Paton 1998). Three isolates of S. flexneri isolated from stool were positive for stx 1 gene and belonged to serotype $2 a(n=2)$ and serotype $y$, $(n=1)$. The amplified fragments were sequenced and identity was confirmed.

Cases of shigellosis are systematically investigated as provincial regulations of notifiable diseases permits. The first case was a 62-year-old man of Haitian origin living in Montreal (isolate ID123699). He was admitted to a hospital for bloody diarrhea, fever, and abdominal pain. Empirical antimicrobial treatment with ciprofloxacin was prescribed and the patient was discharged 2 days after admission. The second case was a 55-year-old man of Haitian origin living in Montreal (Isolate ID132104). Ciprofloxacin was prescribed in an outpatient clinic where he consulted for bloody diarrhea, fever, and abdominal pain. Both cases developed diarrhea the day before their return from Haiti. The third case was a 55-year-old man of Haitian origin living in Montreal (Isolate ID124391). The patient had a non-acute clinical illness with occasional blood in his stool without fever or abdominal pain. He was treated with ciprofloxacin. Travel 
49 information was unavailable and epidemiological links were not obtainable. No clinical 50 complications including hemolytic uremic syndrome (HUS) was observed in any of the three 51 patients. Two patients reported foreign travel to Haiti, confirming the finding of Gray et al. (Gray 52 et al. 2014) regarding the local emergence of these strains.

53 Pulsed-field gel electrophoresis (PFGE) with XbaI and BlnI enzymes did not demonstrate any 54 close genetic link between the three strains.

55 Treatment of STEC infection consists of supportive care and the use of antibiotics remains a 56 matter of debate. In contrast, Shigella infections require antibiotic treatment in many instances 57 and early antimicrobial administration was associated with decreased Stx concentrations in stool 58 and a lowered risk of HUS in stx1-S. dysenteriae infections (Bennish et al. 2006). In this study, 59 the 3 patients were successfully treated with ciprofloxacin without complications and this 60 supports handling Stx1-producing S. flexneri in a similar way to S. dysenteriae.

61 With this recent introduction of $S$. flexneri isolates carrying Shiga Toxin 1 to Canada, 62 identification of Stx production in Shigella spp. should be furthered studied in order to clarify 63 implications in virulence, treatment, and infection prevention and control management. 


\section{References}

Bennish, M.L., Khan, W.A., Begum, M., Bridges, E.A., Ahmed, S., Saha, D., Salam, M.A., Acheson, D., and Ryan, E.T. 2006. Low risk of hemolytic uremic syndrome after early effective antimicrobial therapy for Shigella dysenteriae type 1 infection in Bangladesh. Clin. Infect. Dis. 42: 356-362. doi: 10.1086/499236. PMID:16392080

Gray, M.D., Lacher, D.W., Leonard, S.R., Abbott, J., Zhao, S., Lampel, K.A., Prothery, E., Gouali, M., Weill, F.X., and Maurelli, A.T. 2015. Prevalence of Shiga toxin-producing Shigella species isolated from French travellers returning from the Caribbean: an emerging pathogen with international implications. Clin. Microbiol. Infect. 21: 765 e769-765 e714. doi: 10.1016/j.cmi.2015.05.006. PMID: 25980352

Gray, M.D., Lampel, K.A., Strockbine, N.A., Fernandez, R.E., Melton-Celsa, A.R., and Maurelli, A.T. 2014. Clinical isolates of Shiga toxin 1a-producing Shigella flexneri with an epidemiological link to recent travel to Hispaniola. Emerg. Infect. Dis. 20: 1669-1677. doi: 10.3201/eid2010.140292. PMID: 25271406

Nyholm, O., Lienemann, T., Halkilahti, J., Mero, S., Rimhanen-Finne, R., Lehtinen, V., Salmenlinna, S., and Siitonen, A. 2015. Characterization of Shigella sonnei Isolate Carrying Shiga Toxin 2-Producing Gene. Emerg. Infect. Dis. 21: 891-892. doi: 10.3201/eid2105.140621. PMID: 25897522

Paton, A.W., and Paton, J.C. 1998. Detection and characterization of Shiga toxigenic Escherichia coli by using multiplex PCR assays for stx1, stx2, eaeA, enterohemorrhagic E. coli hlyA, rfbO111, and rfbO157. J. Clin. Microbiol. 36: 598-602. PMID: 9464788

Tesh, V.L., and O'Brien, A.D. 1991. The pathogenic mechanisms of Shiga toxin and the Shigalike toxins. Mol. Microbiol. 5: 1817-1822. PMID: 1766367 
5

91 Trepanier, S., Bui, Y.G., Blackburn, M., Milord, F., Levac, E., and Gagnon, S. 2014. Travel92 related shigellosis in Quebec, Canada: an analysis of risk factors. J. Travel Med. 21: 304-309.

93 doi: $10.1111 / \mathrm{jtm}$.12130. PMID: 24889090

94

95 